\title{
Antiinflammatory, antinociceptive and antipyretic effects of hydroethanolic extract from Macrosiphonia velame (A. St.-Hil.) M. Arg. in animal models
}

\author{
Reginaldo Vicente Ribeiro*, Regilane Matos da Silva, \\ Joaquim Corsino da Silva Lima, Domingos Tabajara de Oliveira Martins
}

Department of Basic Sciences in Health, Faculty of Medical Science, Federal University of Mato Grosso

\begin{abstract}
Macrosiphonia velame (Apocynaceae), popularly known as "velame-branco", is mainly used for treating inflammatory conditions. The antiinflammatory, antinociceptive and antipyretic effects of the hydroethanolic extract of the xylopodium from M. velame (HEMv) were evaluated using several animal models. HEMv showed low acute oral toxicity with $\mathrm{LD}_{50}$ of $4.176 \pm 218.5 \mathrm{mg} / \mathrm{kg}$ in mice. In tests of carrageenan and dextran-induced paw edema and carrageenan-induced pleurisy in rats, and croton oilinduced cutaneous dermatitis in mice, HEMv presented systemic and topical antiinflammatory activities. In experiments of nociception induced by acetic acid, formalin and capsaicin in mice, the HEMv evidenced an antinociceptive effect, being active against both inflammatory and neurogenic pain. Additionally, the HEMv prevented brewer's yeast-induced pyrexia in rats. It is likely that the pharmacologic mechanism of HEMv may involve the inhibition of different mediators of the inflammatory response, such as histamine, serotonin, prostaglandins and leukotrienes. A preliminary phytochemical study was also undertaken on HEMv, which revealed the presence of flavonoids, phenolic compounds, pentacyclic triterpenoids, saponins, coumarins, catechins, tannins, and alkaloids. Taken together, these results suggest that $M$. velame extract has antiinflammatory, antinociceptive and antipyretic properties and further validate the traditional use of this plant in inflammatory conditions.
\end{abstract}

Uniterms: Macrosiphonia velame/antiinflammatory effect. Macrosiphonia velame/antinociceptive effect. Macrosiphonia velame/antipyretic effect. Macrosiphonia velame/pharmacognosy/experimentel study.

Macrosiphonia velame (Apocynaceae), conhecida popularmente como velame-branco, é utilizada no tratamento de inflamações. Avaliou-se nesse estudo, os efeitos antiinflamatório, antinociceptivo e antipirético do extrato hidroetanólico do xilopódio de M. velame (HEMv) em modelos animais. O HEMv apresentou baixa toxicidade aguda oral, com $\mathrm{DL}_{50}=4.176 \pm 218,5 \mathrm{mg} / \mathrm{kg}$ nos camundongos. Nos testes de edema de pata por carragenina e dextrana e pleurisia por carragenina em ratos e dermatite cutânea por óleo de croton em camundongos, o HEMv apresentou atividade antiinflamatória sistêmica e tópica. Nos experimentos de nocicepção induzida por ácido acético, formalina e capsaicina em camundongos, o HEMv inibiu a resposta nociceptiva nos três modelos, mostrando-se ativo tanto na dor de origem inflamatória como neurogênica. Adicionalmente, o HEMv bloqueou a hipertermia induzida por levedura de cerveja nos ratos. É provável que os efeitos farmacológicos observados para o HEMv decorram da inibição de mediadores da resposta inflamatória produzidos pelas vias da COX e/ou LOX bem como da inibição da liberação de histamina e serotonina. A análise fitoquímica do HEMv revelou a presença de flavonóides, compostos fenólicos, triterpenóides pentacíclicos, saponinas, cumarinas, catequinas, taninos catéquicos e alcalóides. Estes resultados validam sob o ponto de vista pré-clínico, o uso popular de $M$. velame em processos inflamatórios.

Unitermos: Macrosiphonia velame/efeito antiinflamatório. Macrosiphonia velame/efeito antinociceptivo. Macrosiphonia velame/efeito antipirético/Macrosiphonia velame/farmacognosia/estudo experimental.

\footnotetext{
*Correspondence: R. V. Ribeiro. Pharmacology Division, Department of Basic Sciences in Health, Faculty of Medical Science, Federal University of Mato Grosso. Av. Fernando Correa da Costa, n 2367 - Boa Esperança - 78060-900 Cuiabá - MT, Brazil. E-mail: reginaldo.bio@gmail.com. Fax: (+55) 6536158862
} 


\section{INTRODUCTION}

Macrosiphonia velame (A. St.-Hil.) M. Arg., popularly known as "velame-branco", "velame do campo" or "losna do campo", is one of the most used plants as a medicinal resource by rural populations of central Brazil plateau (Guarim-Neto, Morais, 2003).

In interviews carried out with 15 herbal sellers from Goiania-Goias State, Brazil, M. velame was cited by $90 \%$ of respondents as an effective anti-inflammatory, depurative and antisyphilitic agent (Santos et al., 2004). In Mato Grosso, home preparations made with "velame-branco" are used for different purposes, especially as a treatment for inflammation, skin diseases and as a blood depurative (Macedo, Ferreira, 2004; De La Cruz, 2008).

$M$. velame occurs naturally in soils with gravel cover in areas of Brazilian cerrado. The collection of this plant in an indiscriminate manner coupled with habitat loss due to intensive agriculture, have made this plant rare in the region. In spite of its high usage and risk of extinction, no chemical or pharmacological studies on the plant are available in the literature. Therefore, the aim of the present study was to investigate the anti-inflammatory, antinociceptive and antipyretic effects of hydroethanolic extract of the xylopodium of $M$. velame using experimental animal models.

\section{MATERIAL AND METHODS}

\section{Plant material and extraction}

The xylopodium of M. velame was collected in 2007 in Acorizal, Mato Grosso State, Brazil (GPS coordinates: $\mathrm{S} 15^{\circ} 04^{\prime} 17.3 \mathrm{~W} 56^{\circ} 20^{\prime} 55.5$ ) and taxonomically identified by Dr Rosilene Rodrigues Silva, a researcher from the Herbarium of the Federal University of Mato Grosso (UFMT). The voucher specimen has been preserved at the UFMT Herbarium under the reference number 38.289. The collection was authorized by the Brazilian Institute of Environment and Renewable Natural Resources (IBAMA).

$1 \mathrm{~kg}$ of xylopodium was, cleaned and dried under shade for 7 days at room temperature and shredded in an electric mill (sieve with a mesh size of $5 \mathrm{~mm}$ ) until powder was obtained. Water-ethanol 75\% (1:3 w/v) was added to the powder, which was macerated for 7 days, concentrated in a rotary evaporator under reduced pressure $\left(600 \mathrm{mmHg}\right.$ ), at a temperature of $50^{\circ} \mathrm{C}$, with the residual solvent being eliminated in an oven at $40^{\circ} \mathrm{C}$, obtaining $60.1 \mathrm{~g}$ (yield $6 \%$ ) of hydroethanolic extract $75 \%$ from Macrosiphonia velame (HEMv).

\section{Animals}

Male Wistar rats and male Swiss-albino mice, supplied by the UFMT Animal House, were used in the experiments. The animals were grouped and housed in propylene cages, receiving a standard dry pellet diet (Purina ${ }^{\circledR}$, Labina) and water ad libitum, under controlled temperature conditions $\left(22 \pm 2{ }^{\circ} \mathrm{C}\right)$ and a $12 \mathrm{~h}$ light-dark cycle. For the assays, animals were randomly assigned into groups of 6-8, except for the hippocratic and $\mathrm{LD}_{50}$ tests. Prior to the experiments, the animals were fasted for $18 \mathrm{~h}$. The experimental protocols were previously approved by the Committee for Ethics in Animal Experimentation (CEPA/UFMT).

\section{Preliminary phytochemical analysis}

Phytochemical analysis HEMv of was carried out based on color and precipitation tests, according to Matos (1988).

\section{Acute toxicity assay}

Three mice per group were used and treated orally (p.o.) with doses of 500 to $5,000 \mathrm{mg} / \mathrm{kg}$ of HEMv. A control animal was used for each dose, receiving vehicle only $(10 \mathrm{~mL} / \mathrm{kg})$. All animals were individually observed in open field after the extract or vehicle was administered, at 0,5 , 10,15 and $30 \mathrm{~min} ; 1,2,4$ and $8 \mathrm{~h}$ and, once every day, for 14 days. The results for the general behavioral observations were recorded in a table adapted from Malone (1977). To calculate the $\mathrm{LD}_{50}$ of the extract, HEMv at 3,000, 4,000, 4,500 and $6,000 \mathrm{mg} / \mathrm{kg}$ doses were administered orally, in groups of 10 mice each ( 5 male and 5 female mice). After $24 \mathrm{~h}$, the number of dead animals was verified and $\mathrm{LD}_{50}$ was calculated according to Miller, Tainter (1944).

\section{Rat paw edema induced by carrageenan and dextran}

Rats (180-200g) were treated orally, with vehicle $(10 \mathrm{~mL} / \mathrm{kg}), \mathrm{HEMv}(20$ and $200 \mathrm{mg} / \mathrm{kg})$ and indomethacin $(10 \mathrm{mg} / \mathrm{kg})$ in the carrageenan test, or vehicle, HEMv (50, 200 and $800 \mathrm{mg} / \mathrm{kg}$ ) and cyproheptadine $(5 \mathrm{mg} / \mathrm{kg})$ in the dextran test. After $1 \mathrm{~h}$ of treatment, the edema was induced by subplantar injection of $100 \mu \mathrm{L}$ of lambda carrageenan $(1 \% \mathrm{w} / \mathrm{v}$ in saline $0.9 \%)$ or dextran $(1.5 \% \mathrm{w} / \mathrm{v}$ in saline $0.9 \%$ ) in the left posterior paw of the rats. The contralateral paw received the same volume of saline $0.9 \%$. The volume of the edema of the paw was measured in a plestimograph (7150 model, $\mathrm{Ugo}$ Basile $^{\circledR}$ ) at 0, 60, 120, 180 and $240 \mathrm{~min}$ after injection of carrageenan or 0,30,60 and 120 min after injection of dextran (Winter et al., 1962). 


\section{Carrageenan-induced pleurisy}

Pleurisy was produced in rats (180-200 g) by the intrapleural injection of $0.1 \mathrm{~mL}$ carrageenan at $2 \%$. The animals received the vehicle, $\operatorname{HEMv}(50,200$ and $800 \mathrm{mg} / \mathrm{kg})$ or 0.5 $\mathrm{mg} / \mathrm{kg}$ of dexamethasone orally, $1 \mathrm{~h}$ before the injection of the phlogistic agent. After $6 \mathrm{~h}$, the animals were anesthetized with ethyl ether, their thoracic cavities opened, pleural exsudate collected by aspiration, the volume measured $(\mathrm{mL})$ and the total number of leukocytes quantified in a Neubauer hemocytometer (Vinegar et al., 1981).

\section{Croton oil-induced cutaneous dermatitis}

Mice (25-30 g) were used, topically treated in each ear with $20 \mu \mathrm{L}$ of vehicle, $\operatorname{HEMv}(1,10$ and $100 \mu \mathrm{g})$ or dexamethasone $(5 \mu \mathrm{g})$ incorporated in hostacerin ${ }^{\circledR} \mathrm{NCB}$ formulation. After $6 \mathrm{~h}$ of the injection of the irritant substance, the animals were euthanized by cervical displacement and both ears were extirpated at the base $(6 \mathrm{~mm}$ diameter) and weighed on analytical laboratory scales (Swingle et al., 1981).

\section{Acetic acid-induced writhing test}

Mice (25-30 g) were treated orally with vehicle, HEMv $(20$ and $200 \mathrm{mg} / \mathrm{kg})$ or indomethacin $(5 \mathrm{mg} / \mathrm{kg})$. After $1 \mathrm{~h}, 10 \mathrm{~mL} / \mathrm{kg}$ of acetic acid $0.6 \%$ diluted in saline $0.9 \%$ was injected intraperitoneally into each animal and the animal's contortions (writhings) were counted during the subsequent $30 \mathrm{~min}$ (Koster et al., 1959).

\section{Formalin test}

Mice (25-30 g) received vehicle, $\operatorname{HEMv}(50,200$, $800 \mathrm{mg} / \mathrm{kg})$, indomethacin $(10 \mathrm{mg} / \mathrm{kg})$ or morphine $(10$ $\mathrm{mg} / \mathrm{kg}$ ) orally. After $1 \mathrm{~h}$, each animal received $20 \mu \mathrm{L}$ formaldehyde solution $2.5 \%$ in saline $0.9 \%$ in the subplantar region of the left posterior paw. The time spent licking and / or biting the injected paw was timed during the first $5 \mathrm{~min}\left(1^{\text {st }}\right.$ phase $)$ and during the $20-30 \mathrm{~min}\left(2^{\text {nd }}\right.$ phase $)$ interval which followed the injection of the noxic agent (Hunskaar et al., 1985).

\section{Capsaicin test}

Mice (25-30 g) were pre-treated orally $1 \mathrm{~h}$ before the test with vehicle and $\operatorname{HEMv}(50,200$ and $800 \mathrm{mg} / \mathrm{kg})$, and with morphine $30 \mathrm{~min}$ before administration of the noxic agent. Animals subsequently received $20 \mu \mathrm{L}$ capsaicin $(1.6 \mu \mathrm{g} / \mathrm{paw})$, injected into the subplantar region of the left posterior paw, and the time period the animal kept licking and / or biting the paw over the 5 min that followed was timed and recorded (Sakurada et al., 1992).

\section{Brewer's yeast induced pyrexia}

Rats (160-180 g) received, subcutaneously, $5 \mathrm{mg}$ of a $20 \%$ brewer's yeast suspension in sterile saline $0.9 \%$ $(\mathrm{w} / \mathrm{v})$. After $21 \mathrm{~h}$ (zero time), the rectal temperature was monitored for 1 min using a clinical thermometer introduced $3 \mathrm{~cm}$ into the rectal ampoule. Subsequently, vehicle, $\operatorname{HEMv}(50,200$ and $800 \mathrm{mg} / \mathrm{kg})$ or diclophenac sodium $(30 \mathrm{mg} / \mathrm{kg}$ ) were administered, and the rectal temperature taken again 1, 2 and $3 \mathrm{~h}$ after treatment. Another group received $5 \mathrm{~mL} / \mathrm{kg}$ sterile saline $0.9 \%$, instead of brewer's yeast. After the recommended time, the vehicle was administered orally and rectal temperature was taken (Al-Ghamdi, 2001).

\section{Rota-rod performance test}

Male mice (25-30 g) were pre-selected $24 \mathrm{~h}$ in advance to eliminate those animals which could not stay on the bar for a period of $60 \mathrm{~s}$. Animals were treated orally with vehicle, $\operatorname{HEMv}(50,200$ and $800 \mathrm{mg} / \mathrm{kg})$ or intraperitoneally with diazepam $(5 \mathrm{mg} / \mathrm{kg})$. The maximum period of time was $60 \mathrm{~s}$, with up to 3 reintroductions to the rotarod (Letica LI 8200) were allowed (Rosland et al., 1990).

\section{Statistical analysis}

Results for the parametric tests were expressed as mean \pm standard error of the mean (S.E.M.). Statistical significance was determined by one-way analysis of variance (ANOVA), followed by Student-Newman-Keuls post-test, with $p$ values $<0.05$ considered significant.

\section{RESULTS}

\section{Preliminary phytochemical analysis}

The preliminary phytochemical study carried out with HEMv showed the presence of alkaloids, catechins, phenolic compounds, coumarins, flavonoids, flavonones, saponins, condensed tannins and pentacyclic triterpenoids.

\section{Acute toxicity test}

Doses up to $1,000 \mathrm{mg} / \mathrm{kg}$ caused no behavioral alteration in the animals. Reduction in mobility and respiratory frequency was noted at 2,000 and 5,000 mg/kg 
of HEMv, as well as mild analgesia (evidenced by tail compression), causing death of $2 / 3$ of the animals at the highest dose, with $\mathrm{LD}_{50}=4,176 \pm 218.5 \mathrm{mg} / \mathrm{kg}$, p.o.

\section{Carrageenan and dextran-induced paw edema}

In the carrageenan-induced paw edema, animals which received the vehicle presented a slow edema evolution, reaching peak inflammatory response in the $3^{\text {rd }}$ hour $(0.60 \pm 0.03 \mathrm{~mL})$. The 20 and $200 \mathrm{mg} / \mathrm{kg}$ of HEMv reduced the paw edema in the $1^{\text {st }} \mathrm{h}(30$ and $26.6 \%, \mathrm{p}<0.01$, respectively), whereas only the lowest dose was active in the $3^{\text {rd }}$ $\mathrm{h}$, with $21.6 \%(\mathrm{p}<0.01)$ edema inhibition. Indomethacin $(10 \mathrm{mg} / \mathrm{kg})$ was more active than HEMv, inhibiting edemas at all periods of time and reaching maximum effect in the $3^{\text {rd }} \mathrm{h}(0.38 \pm 0.03 \mathrm{~mL}, \mathrm{p}<0.001)$ (Figure 1).

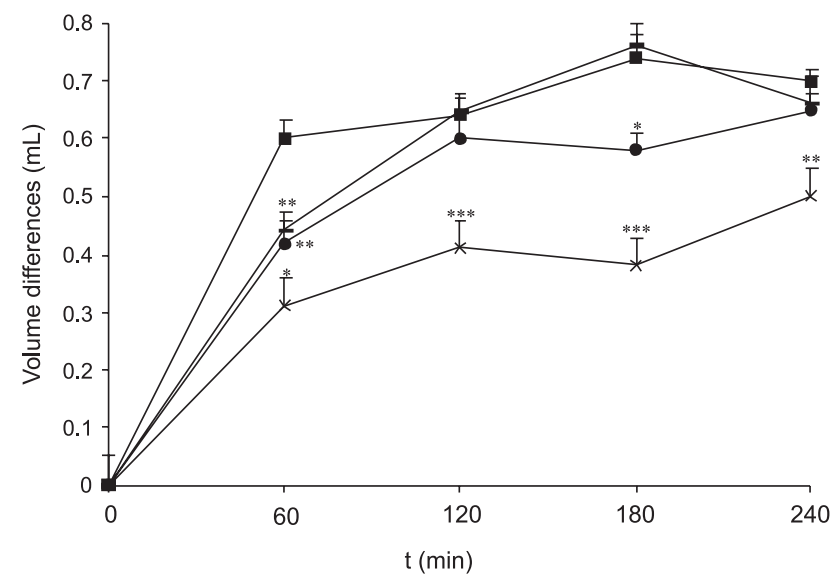

FIGURE 1 - Effect of oral treatment with vehicle(ם), hydroethanolic extract of M. velame (HEMv) at doses of $20(\bullet)$ and $200 \mathrm{mg} / \mathrm{kg}$ $(\bullet)$, or $10 \mathrm{mg} / \mathrm{kg}$ of indomethacin $(\times)$, on carrageenan-induced paw edema in rats. Each value is the mean \pm S.E.M. of 6-8 rats. ${ }^{*} \mathrm{p}<0.05, * * \mathrm{p}<0.01, * * * \mathrm{p}<0.001$ compared with control. One-way ANOVA followed by Student-Newman-Keuls.

In the dextran-induced paw edema, rats treated with vehicle developed edema rapidly from the onset with intensity, reaching its peak within $30 \mathrm{~min}(0.84 \pm 0.8 \mathrm{~mL})$. HEMv (200 and $800 \mathrm{mg} / \mathrm{kg}$ ) reduced the edema by $26.2 \%$ and $29.8 \%$ $(\mathrm{p}<0.05)$, respectively, after $60 \mathrm{~min}$ of the phlogistic agent injection. Cyproheptadine $(5 \mathrm{mg} / \mathrm{kg}$, p.o.) caused intense edema inhibition, starting from $30 \mathrm{~min}$ and maintaining inhibition up to the $2^{\text {nd }}$ hour $(54.3 \%, \mathrm{p}<0.01)$ of the experiment (Figure 2$)$.

\section{Carrageenan-induced pleurisy}

In the control group, the intrapleural injection of carrageenan $2 \%$ caused plasma leakage $(1.74 \pm 0.06 \mathrm{~mL})$ and leukocyte infiltration $\left(81.4 \pm 1.8 \times 10^{6}\right.$ cells $)$.

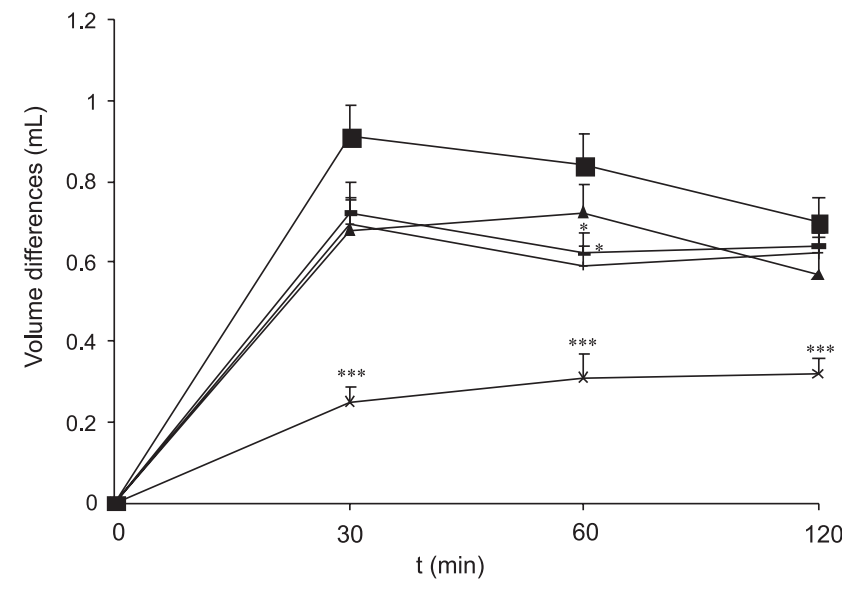

FIGURE 2 - Effect of oral treatment with vehicle (ם), hydroethanolic extract of $M$. velame (HEMv) at doses of $50(\boldsymbol{\Delta}), 200(-)$ and $800(+) \mathrm{mg} / \mathrm{kg}$, or $5 \mathrm{mg} / \mathrm{kg}$ of cyproheptadine $(\times)$, on dextran-induced paw edema in rats. Each value is the mean \pm S.E.M. of $7-8$ rats. $* p<0.05$ and $* * * p<0.001$ compared with control. One-way ANOVA followed by StudentNewman-Keuls.

$\operatorname{HEMv}(50,200$ and $800 \mathrm{mg} / \mathrm{kg})$ reduced plasma exudation and cell migration, in a dose-dependent manner, reaching its strongest effect with an $800 \mathrm{mg} / \mathrm{kg}$ dose ( $17.8 \%-p<0.01$ and $40.3 \%-p<0.001$, respectively). Dexamethasone $(0.5 \mathrm{mg} / \mathrm{kg})$ reduced both exudation $(74.1 \%$, $\mathrm{p}<0.001)$ and leukocyte infiltration $(71.6 \%, \mathrm{p}<0.001)$ more intensively than HEMv (Figure 3).

\section{Croton oil-induced cutaneous dermatitis}

The topical administration of $100 \mu \mathrm{g}$ croton oil caused an increase of $6.07 \pm 0.50 \mathrm{mg}$ in the weight of control mice ears. The local treatment with HEMv $(100 \mu \mathrm{g} /$ ear $)$ in hostacerin ${ }^{\circledR} \mathrm{NCB}$ reduced ear edema by $50.4 \%(\mathrm{p}<0.05)$, whereas $5 \mu \mathrm{g}$ dexamethasone reduced edema by $69.2 \%$ $(\mathrm{p}<0.01)$ (Figure 4).

\section{Acetic acid-induced writhing in mice}

The intraperitoneal injection of acetic acid (0.6\%) caused strong nociceptive response in the control group, with $43.3 \pm 2.8$ abdominal contortions. Treating animals with HEMv (20 and $200 \mathrm{mg} / \mathrm{kg}$ ) inhibited writhings caused by acetic acid by 57 and $72 \%(\mathrm{p}<0.001)$, respectively. Indomethacin $(5 \mathrm{mg} / \mathrm{kg})$, the standard for this kind of experiment, reduced contortions by $91 \%(\mathrm{p}<0.001)$ (Figure 5$)$.

\section{Formalin test}

The injection of formalin $(2.5 \%)$ coused in the control 
group a characteristic biphasic response (Figure 6). The duration of licking was $68.0 \pm 2.6 \mathrm{~s}$ in the $1^{\text {st }}$ phase $(0-5 \mathrm{~min})$ and $70.6 \pm 4.9 \mathrm{~s}$ in the second phase $(20-30 \mathrm{~min})$. The results show that, in the $1^{\text {st }}$ phase, HEMv was active only at an 800 $\mathrm{mg} / \mathrm{kg}$ dose, reducing the nociceptive response by $54.7 \%$ $(\mathrm{p}<0.001)$, whereas in the $2^{\text {nd }}$ phase $H E M v$ was active for all
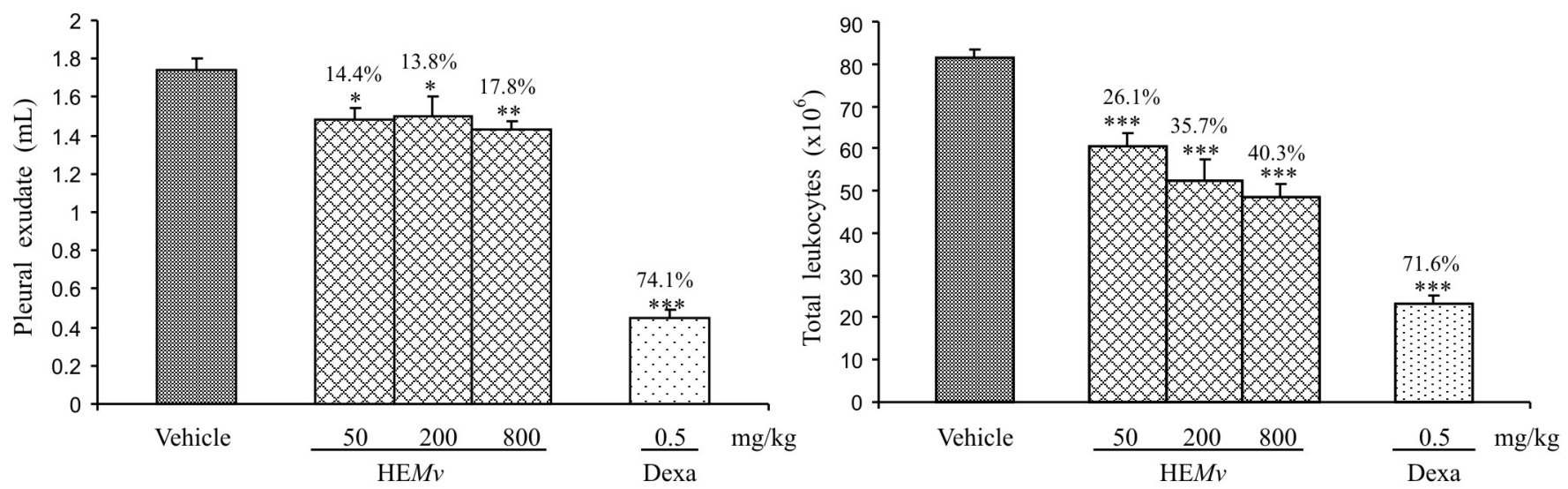

FIGURE 3 - Effect of hydroethanolic extract of $M$. velame on exudate and cell migration carrageenan-induced in rats. Each value is the mean \pm S.E.M. of $7-8$ rats. ${ }^{*} p<0.05,{ }^{*} p<0.01,{ }^{* * *} p<0.001$ compared with control. One-way ANOVA followed by StudentNewman-Keuls.

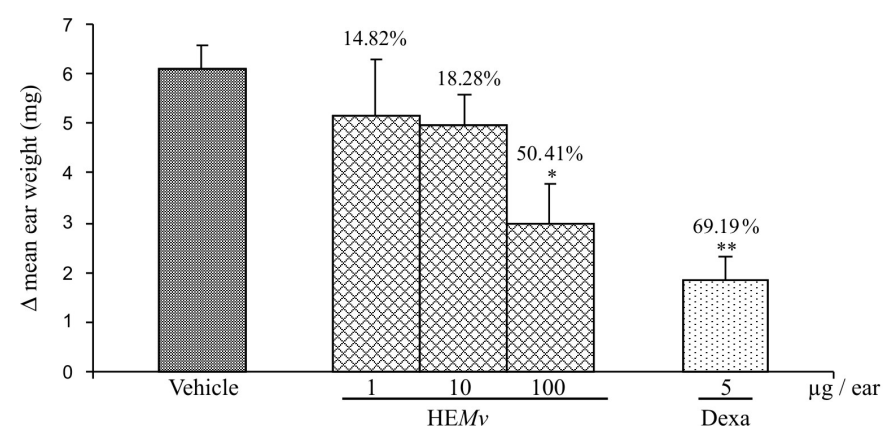

FIGURE 4 - Effect of hydroethanolic extract of M. velame in hostacerin ${ }^{\circledR}$ on croton oil-induced cutaneous dermatitis in mice. Each value is the mean \pm S.E.M. of 7-8 rats. $* p<0.05$ and $* * p<0.01$ compared with control. One-way ANOVA followed by Student-Newman-Keuls.

$$
1^{\text {st }} \text { phase }
$$

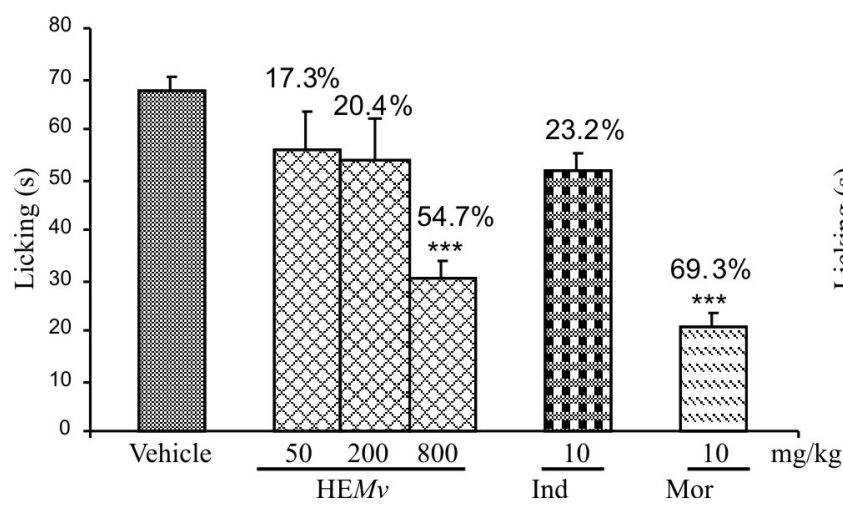

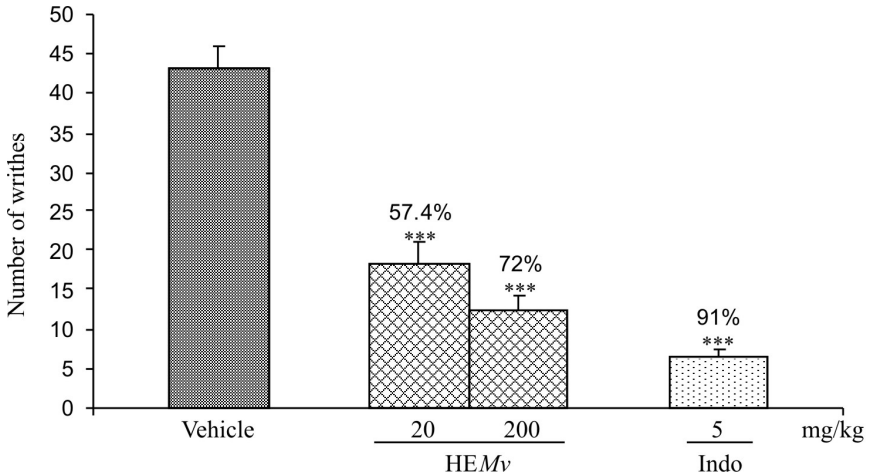

FIGURE 5 - Effect of hydroethanolic extract of M. velame on acetic acid-induced writhing in mice. Values are expressed as mean \pm S.E.M. $(n=7-8)$. One-way ANOVA followed by StudentNewman-Keuls test. Significantly different to control, ${ }^{* * *} \mathrm{p}<0.001$.

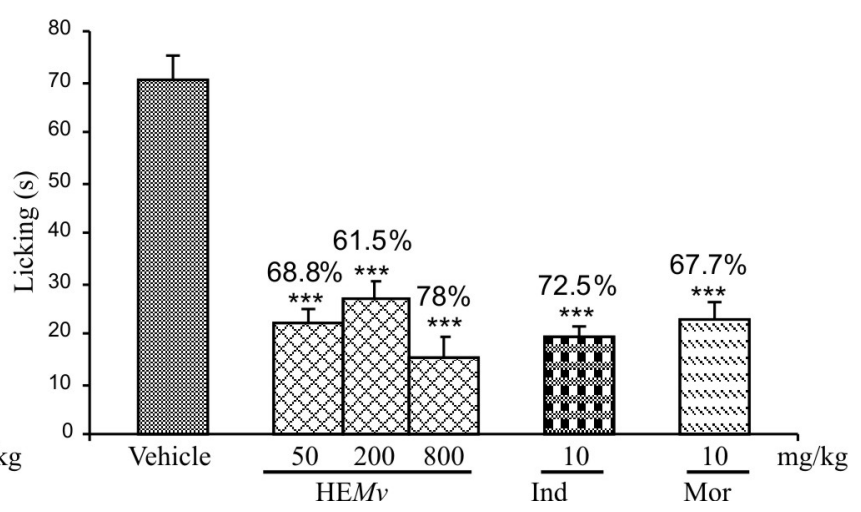

FIGURE 6 - Effect of hydroethanolic extract of $M$. velame on the $1^{\text {st }}$ and $2^{\text {nd }}$ phases of pain induced by formalin injection in mice. Each value is the mean \pm S.E.M. of 8 rats. ${ }^{* *}$ p $<0.001$ compared with control. One-way ANOVA followed by Student-NewmanKeuls. 


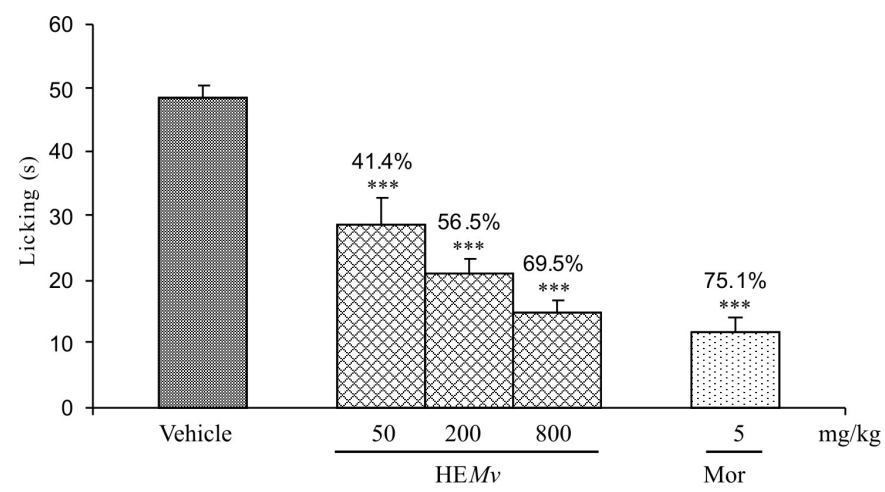

FIGURE 7 - Effect of hydroethanolic extract of $M$. velame on capsaicin induced nociception in mice. Each value is the mean \pm S.E.M. of 7-8 rats. ${ }^{* * *} \mathrm{p}<0.001$ compared with control. One-way ANOVA followed by Student-Newman-Keuls.

doses $(50,200$ and $800 \mathrm{mg} / \mathrm{kg})$, reaching its maximum effect at the highest dose $(78 \%, \mathrm{p}<0.001)$, exceeding even the 10 $\mathrm{mg} / \mathrm{kg}$ indomethacin effect $(72.5 \%, \mathrm{p}<0.001)$. Morphine (10 $\mathrm{mg} / \mathrm{kg}$, p.o.) was shown to be equally effective in inhibiting the pain response, both in the $1^{\text {st }}$ and $2^{\text {nd }}$ phases, with 69.3 and $67.7 \%(\mathrm{p}<0.001)$ reductions, respectively.

\section{Capsaicin test}

The results presented in Figure 7 showed that HEMv $(20,200$ and $800 \mathrm{mg} / \mathrm{kg}$, p.o.) caused significant and dosedependent capsaicin-induced neurogenic pain inhibition. At the highest HEMv dose, responses reached a similar intensity $(69.5 \%, \mathrm{p}<0.001)$ to that obtained with $5 \mathrm{mg} / \mathrm{kg}$ morphine $(75.1 \%, \mathrm{p}<0.001)$, administered subcutaneously.

\section{Brewer's yeast-induced pyrexia}

The subcutaneous injection of $20 \%$ brewer's yeast suspension substantially increased the rectal temperature of the rats $21 \mathrm{~h}$ after administration $\left(38.3 \pm 0.13{ }^{\circ} \mathrm{C}\right.$ vs. $37.1 \pm$ $\left.0.16^{\circ} \mathrm{C}, \mathrm{p}<0.001\right) . \mathrm{HE} M v$ treatment at 200 and $800 \mathrm{mg} / \mathrm{kg}$ doses significantly reduced the rectal temperature of the animals in the $2^{\text {nd }}$ and $3^{\text {rd }}$ hours after administration, reaching peak antipyretic effect at the highest dose in the $2^{\text {nd }}$ hour $\left(37.5 \pm 0.08{ }^{\circ} \mathrm{C}, \mathrm{p}<0.001\right)$ compared to controls $\left(38.5 \pm 0.01^{\circ} \mathrm{C}\right)$. Diclophenac sodium treatment $(30 \mathrm{mg} / \mathrm{kg})$ caused significant reduction in rectal temperature at all periods of time, reaching peak antipyretic effect in the $2^{\text {nd }}$ hour among all groups $(37.0 \pm 0.09, \mathrm{p}<0.001)$, compared to control $\left(38.3 \pm 0.08^{\circ} \mathrm{C}\right.$ ) (Figure 8$)$.

\section{Rota-rod performance test}

Treating mice with HEMv (50, 200 and $800 \mathrm{mg} / \mathrm{kg})$

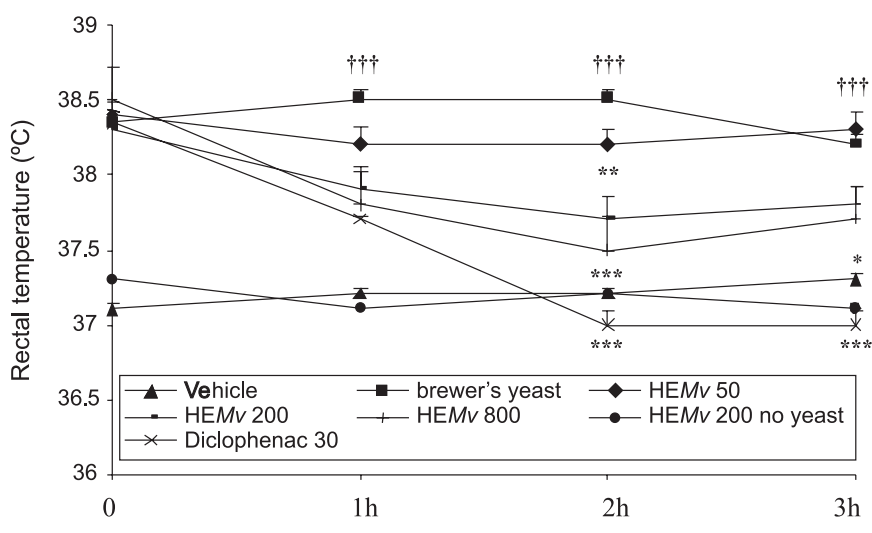

FIGURE 8 - Effect of hydroethanolic extract of $M$. velame on brewer's yeast induced pyrexia in rats. Each value is the mean \pm S.E.M. of 6-8 rats. ${ }^{*} p<0.05,{ }^{* *} \mathrm{p}<0.01,{ }^{* * *} \mathrm{p}<0.001$ compared with control or $\dagger \dagger \dagger p<0.001$ compared with yeast. One-way ANOVA followed by Student-Newman-Keuls.

presented no significant alterations $(\mathrm{p}>0.05)$ in motor coordination of the mice on the experimental spinning bar at any of the observed times, unlike the animals which received diazepam $(5 \mathrm{mg} / \mathrm{kg})$, whose time of permanence on the spinning bar was lower $(33.4 \pm 5.3 \mathrm{~s}, \mathrm{p}<0.001)$ compared to the control group ( $60 \pm 0 \mathrm{~s})$.

\section{DISCUSSION}

With the aim of providing the first scientific evidence for the popular use of $M$. velame, the pharmacological effects of HEMv were investigated, particularly those related to the inflammatory process.

The carrageenan-induced paw edema model has frequently been used to evaluate the antiedematogenic effect of most anti-inflammatory drugs in routine clinical use (Carvalho et al., 1999). Reports describe that several mediators are released through the injection of carrageenan in the rat's paw; while histamine, serotonin and bradykinin are released in the initial phase $(0-1 \mathrm{~h})$, in the later phase (1-6 h) there is an increase in the production levels of prostaglandins (PGs) through the activation of cyclooxygenase-2 (COX-2) and release of nitric oxide (NO) (Silva et al., 2005).

In the carrageenan test, HEMv (20 and $200 \mathrm{mg} / \mathrm{kg}$ ) exerted significant edema inhibition, albeit to a lesser degree than indomethacin $(10 \mathrm{mg} / \mathrm{kg})$, a non-selective COX-inhibitor that decreases PG production (Farsam et al., 2000).

It is known that histamine and serotonin are the principal inflammatory mediators involved in the dextraninduced paw edema (Lo et al., 1982). HEMv caused significant inhibition of dextran-induced edema, suggesting 
that it could interfere with either the degranulation of mast cells, and the consequent release of histamine and serotonin, or with their receptor actions.

Pleurisy and paw edema induced by carrageenan are considered the most appropriate experimental models for evaluating anti-inflammatory substances (Otterness, Gans, 1988). Leukocyte migration to the inflammation site is a key event in the inflammatory process. The injection of carrageenan in the pleural cavity of rodents causes an acute inflammatory response, characterized by accumulation of fluids, and a large number of polymorphonuclear leukocytes (PML) in the pleural cavity. This causes lipid peroxidation and increased production of PGs, leukotrienes, reactive oxygen species and cytokines such as TNF- $\alpha$ and IL1- $\beta$ (Di Paola et al., 2004). Our results suggest that the plant extract may impact the production of these mediators thereby exerting an anti-inflammatory effect in this pleurisy model.

Croton oil is an irritant agent that induces an inflammatory response when applied to the ear skin through activation of phospholipase $\mathrm{A}_{2}$ and by initiation of arachidonate metabolism. The released arachidonic acid in turn is metabolized by COX and LOX enzymes promoting the production of eicosanoids and leukotrienes. As a consequence, there is an increase in vascular permeability and hydrostatic pressure, resulting in edema formation and migration of neutrophils to the damaged area. The ear edema reaches its peak in the $6^{\text {th }}$ hour, as a result of the formation of the arachidonic acid metabolites and other pro-inflammatory mediators (Swingle et al., 1981). This experimental model is used to detect COX and or LOX in vivo inhibition activity, being very sensitive to steroidal antiinflammatory drugs (SAIDs) and less sensitive to NSAIDs (Swingle et al., 1981; Young et al., 1984). In this model, topical application of HEMv $(100 \mu \mathrm{g})$ produced a significant antiedematogenic effect, similar in intensity to the result observed with $5 \mu \mathrm{g}$ dexamethasone. Although the present study established the efficacy of HEMv as an anti-inflammatory agent, its exact mechanism and the mediators involved have yet to be elucidated.

Besides antiinflammatory activity, HEMv demonstrated antinociceptive properties in the experimental models of nociception induced by acetic acid, formalin and capsaicin.

The abdominal contortions test induced by acetic acid - a visceral pain model - despite its high sensitivity and low specificity, is described as a typical model to relieve inflammatory pain (Braggio et al., 2002). The local irritation caused by intraperitoneal administration of this agent, unleashes the release of several mediators, such as bradykinin, substance $\mathrm{P}$ and PGs, as well as cytokines such as IL- $1 \beta$, TNF- $\alpha$ and IL- 8 . These mediators activate chemosensitive nociceptors which contribute to the development of inflammatory pain. HEMv (20 and $200 \mathrm{mg}$ / $\mathrm{kg}$ ) inhibited the mice nociceptive response to acetic acid in a significant and dose-dependent manner, suggesting suppression of inflammatory pain through the inhibition of release/activity of inflammatory mediators (Sekiya, Okuda, 1982).

The formalin test is more specific and frequently used in the study of nociception. The injection of formalin produces a particular biphasic response: the $1^{\text {st }}$ phase involves the release of glutamate excitatory amino acid and sensorial neuropeptides, such as the substance P released from spinal cord sensorial neurons, whereas the $2^{\text {nd }}$ phase depends basically on the liberation of inflammatory mediators and on functional changes in the spinal cord dorsal horn (Otuki et al., 2001). The HEMv blocked the licking response in both phases (the first phase response at the highest dose and $2^{\text {nd }}$ phase at all doses), indicating that the extract is also effective against formalin-induced nociception.

Previous studies have shown that capsaicin induces the release of neurokinins, neuropeptides, excitatory amino acids (glutamate and aspartate), NO and proinflammatory peripheral mediators, besides promoting the transmission of nociceptive information to the spinal cord and the activation of vanilloid receptors (Caterina, Julius 2001). The inhibition of capsaicin-induced nociception suggests that HEMv may possibly interfere with the release of neuropeptides or their receptor activation.

The possibility of the HEMv antinociceptive effect being the result of motor deficits or CNS depression can be ruled out since the extract did not impair the animals' motor performance on the rota-rod apparatus.

These results The results in nociceptive tests indicate that HEMv has antinociceptive potential but does not define the exact mechanism, and further does not delineate whether its action is central or peripherally mediated.

The brewer's yeast-induced pyrexia test is of great relevance, as most NSAIDs inhibit the hyperthermal response. The injection of $20 \%$ brewer's yeast causes release of pro-inflammatory cytokines which, upon reaching circulation, stimulate the synthesis of $\mathrm{PGE}_{2}$ in the surroundings of the hypothalamic thermoregulator centers (Chan, Fiscus, 2004). HEMv (200 and $800 \mathrm{mg} / \mathrm{kg}$ ) reduces the yeast-induced hyperthermia.

HEMv does not appear to cause any kind of acute toxicity when administered through orogastric gavage in the pharmacological assays, presenting a high $\mathrm{LD}_{50}(4,176$ $\pm 218.5 \mathrm{mg} / \mathrm{kg}$, p.o.), suggesting low oral toxicity.

The preliminary phytochemical studies with HEMv revealed the presence of alkaloids, catechins, phenolic 
compounds, coumarins, flavonoids, saponins, condensed tannins and pentacyclic triterpenoids, having been previously described for its many pharmacological effects, including antiinflammatory, antinociceptive and antipyretic activities (Safayhi, Sailer et al., 1997; Silva et al., 2002, Tuñón et al., 2009).

Although the exact nature of the antiinflammatory, antinociceptive and antipyretic activity mechanisms of the phytoconstituents have not been elucidated, the results of the present study validate from a pre-clinical point-of-view, the popular use of this medicinal plant in the treatment of inflammatory diseases.

\section{ACKNOWLEDGEMENTS}

Coordenação de Aperfeiçoamento de Pessoal de Nível Superior/CAPES, Conselho Nacional de Desenvolvimento Científico e Tecnológico/CNPq and Pantanal Research Center (Centro de Pesquisa do Pantanal/Cuiabá/ MT) for the financial support.

\section{REFERENCES}

AL-GHAMDI, M.S. The anti-inflammatory, analgesic and antipyretic activity of Nigella sativa. J. Ethnopharmacol., v.76, n.1, p.45-48, 2001.

BRAGGIO, M.M.; LIMA, M.E.L.; VEASEY, E.A.; HARAGUCHI, M. Atividades farmacológicas das folhas da Sesbania virgata (Cav.) Pers. Arq. Inst. Biol., v.69, n.4, p.49-53, 2002.

CARVALHO, J.C.T.; FERREIRA, L.P.; DA SILVA, S.L.; CORREA, M.J.C.; OLIVEIRA, C.L.M.; BASTOS, J.K.; SARTI, S.J. Anti-inflammatory activity of flavone and some of its derivates from Virola michelli Heckel. J. Ethnopharmacol., v.64, n.2, p.173-177, 1999.

CATERINA, M.J.; JULIUS, D. The vanilloid receptor: A molecular gateway to the pain pathway. Ann. Rev. Neurosci., v.24, n.1, p.487-517, 2001.

CHAN, G.H.; FISCUS, R.R. Exaggerated production of nitric oxide (NO) and increases in inducible NO-synthase mRNA levels induced by the pro-inflammatory cytokine interleukin- beta in vascular smooth muscle cells of elderly rats. Exp. Gerontol., v.39, n.3, p.387-394, 2004.

DE LA CRUZ, M.G. Plantas medicinais de Mato Grosso: a farmacopéia popular dos raizeiros. Cuiabá-MT: Carlini \& Caniato, 2008. p.127-128.
DI PAOLA, R.; DI MARCO, R.; MAZZON, E.; GENOVESE, T.; BENDTZEN, K.; MACRI, B.; NICOLETTI, F.; CUZZOCREA, S. Prevention of carrageenan-induced pleurisy in mice by anti-CD30 ligand monoclonal antibody. Clin. Immunol., v.13, n.1, p.64-73, 2004.

FARSAM, H.; AMANLOU, M.; DEHPOUR, A.R.; JAHANIANI, F. Anti-inflammatory and analgesic activity of Biebersteinia multifida DC. root extract. $J$. Ethnopharmacol., v.71, n.3, p.443-447, 2000.

GUARIM-NETO, G.; MORAIS, R.G. Recursos medicinais de espécies do cerrado de Mato Grosso: um estudo bibliográfico. Acta Bot. Bras., v.17, n.4, p.561-584, 2003.

HUNSKAAR, S.; FASMER, O.B.; HOLE, K. Formalin test in mice, a useful technique for evaluating mild analgesics. $J$. Neurosci. Methods, v.14, n.1, p.69-76, 1985.

LO, T.N.; ALMEIDA, A.P.; BEAVEN, M.A. Dextran and carrageenan evoke different inflammatory responses in rat with respect to composition of infiltrates and effect of indomethacin. J. Pharmacol. Exp. Ther., v.221, n.1, p.261267, 1982.

KOSTER, R.; ANDERSON, M.D.; BEER, E.J. Acetic acid for analgesic screening. Fed. Proc., v.18, n.1, p.412-414, 1959.

MACEDO, M.; FERREIRA, A.R. Plantas medicinais usadas para tratamento dermatológicos, em comunidades da Bacia do Alto Paraguai, Mato Grosso. Rev. Bras. Farmacogn., v.14, n.1, p.40-44, 2004.

MALONE, M.H. Pharmacological approaches to natural products screening and evaluation. In: WAGNER, H.; WOLFF, P. (Eds.). New natural products and plant drugs with pharmacological, biological or therapeutical activity. Berlin: Spriger-Verlag, 1977. p.23-53.

MATOS, F.J.A. Introdução à fitoquímica experimental. Fortaleza: Imprensa Universitária da Universidade Federal do Ceará, 1988. 128 p.

MILLER, L.C.L.; TAINTER, M.L. Estimation of the $\mathrm{ED}_{50}$ and it's error by means of logarithmic probit graph paper. Proc. Soc. Exp.Biol. Med., v.57, n.1, p.261-264, 1944.

OTTERNESS, I.G.; GANS, D.J. Nonsteroidal anti-inflammatory drugs: An analysis of the relationship between laboratory animal and clinical doses, including species scaling. $J$. Pharm. Sci., v.77, n.9, p.790-795, 1988. 
OTUKI, M.F., LIMA, F.V., MALHEIROS, A., CECHINELFILHO, V., MONACHE, F.D., YUNES, R.A.,CALIXTO, J.B. Evaluation of the antinociceptive action caused by ether fraction and a triterpene isolated from resin of Protium kleinii. Life Sci., v.69, n.19, p.2225-2236, 2001.

ROSLAND, J.H.; HUNSKAAR, S.; HOLE, K. Diazepam attenuates morphine antinoceptive test dependently in mice. Pharmacol. Toxicol., v.66, n.5, p.382-386, 1990.

SAFAYHI, H.; SAILER, E.R. Antiinflammatory actions of pentacyclic triterpenes. Planta Med., v.63, n.1, p.487-493, 1997.

SAKURADA, T.; KATSUMATA, K.; TAN-NO, K.; SAKURADA, S.; KISARA, K. The capsaicin test in mice for evaluating tachykinin antagonists in the spinal cord. Neuropharmacology, v.31, n.12, p.1279-1285, 1992.

SANTOS, E.N.; SOUZA, R.B.L.; OLIVEIRA, T.L.S.; CARMO, F.M.; RIBEIRO, J.B.C.; CARMO, F.M.; MOTA, D.K.A.S. Plantas medicinais indicadas como antiinflamatórias por "raizeiros" da Região de Goiânia- GO. Infarma, v.16, n.12, p.80-82, 2004.

SEKIYA, K.; OKUDA, H.; ARICHI, S. Selective inhibition of platelet lipoxygenase by esculetin. Biochim. Biophys. Acta, v.713, n.1, p.68-72,1982.

SILVA, M.G.; OLIVEIRA, F.S.; QUINTANS-JÚNIOR, L.J.; THENIO, O.M.L.; DINIZ, M.F.M. Investigação do efeito analgésico central e antiinflamatório de Conocliniopsis prasiifolia (DC) R.M. King \& H. Rob. em roedores. Acta Farm. Bon, v.24, n.4, p.533-537, 2005.
SILVA, R.R.; OLIVEIRA, T.T.; NAGEM, T.J.; LEÃO, M.A. Efeito de flavonóides no metabolismo do ácido araquidônico. Medicina Ribeirão Preto, v.35, n.2, p.127133, 2002.

SWINGLE, K.F.; REITER, M.J.; SCHWARTZMILLER, D.H. Comparison of croton oil and cantharidin induced inflammations of the mouse ear and their modification by topically applied drugs. Arch. Int. Pharmacodyn. Ther. v.254, n.1, p.168-176, 1981.

TUÑÓN, M.J.; GARCÍA-MEDIAVILLA, M.V.; SÁNCHEZCAMPOS S.; GONZÁLEZ-GALLEGO, J. Potential of flavonoids as anti-inflammatory agents: modulation of pro-inflammatory gene expression and signal transduction pathways. Curr. Drug Metab., v.10, n.3, p.256-271, 2009.

VINEGAR, R.; TRUAX, J.F.; SELPH, J.L.; JOHNSTON, P.R.; VENABLE, A.L.; VOELKER, F.A. Development of carrageenan pleurisy in the rat: effects of colchicine on inhibition of cell mobilization. Proc. Soc. Exp. Biol. Med., v.168, n.1, p.24-32, 1981

WINTER, C.A.; RISLEY, E.A.; NUSS, G.W. Carrageenininduced edema in hind paw of the rat as an assay for antiinflammatory drugs. Proc. Soc. Exp. Biol. Med., v.111, n.1, p.544-547, 1962.

YOUNG, J.M.; SPIRES, D.A.; BEDORD, C.J.; WAGNER, B.; BALLARON, S.J.; DE YOUNG, L.M. The mouse ear inflammatory response to topical arachidonic acid. J. Invest. Dermatol., v.82, n.4, p.367-711, 1984.

Received for publication on $11^{\text {th }}$ June 2009 Accepted for publication on $10^{\text {th }}$ December 2009 